\title{
DESIGN AND FABRICATION OF A MATERIAL RECOVERY FACILITY FOR INSTITUTIONAL WASTES TO MITIGATE CARBON EMISSIONS IN SOUTH- WEST NIGERIA
}

\author{
Akinjogbin I. O. \\ Department of Building Technology \\ Federal Polytechnic, Ede, Nigeria \\ Prof M. K. C. Sridhar \\ Department of Environmental Health Sciences, Faculty of Public Health, College of Medicine \\ University of Ibadan, Ibadan, Nigeria \\ Prof Coker A. O. \\ Civil Engineering Department \\ University of Ibadan, Ibadan, Nigeria
}

Abstract- Managing of institutional wastes is similar to any other municipal solid wastes (MSW) which in many cases had created a lot of environmental challenges. Methods like sanitary landfill, incineration and open burning were usually adopted. This methods in turn causes additional harm such as greenhouse gas (GHG) emissions to the environment. Source sorting have been found to minimize GHG emission especially when the components segregated are recycled. Non commitment of major stakeholders to source sorting calls for the development of a Semi Automated Material Recovery Facility to aid an effective management of the wastes. The wastes generated, collected and disposed of in one academic session was monitored at Federal Polytechnic, Ede, South-West Nigeria to determine the, quantity, component and its management. Through these assessments, the quantity and composition of wastes generated and deposited at the dump site of the institution as well as Carbon Dioxide $\left(\mathrm{CO}_{2}\right)$ emissions resulting from the management of the generated wastes in the polytechnic were determined. A Semi Automated Material Recovery Facility (SAMRF) was designed, fabricated and implemented for proper waste management to mitigate against $\mathrm{CO}_{2}$ emissions resulting from the institution's MSW management methods. The performance of the SAMRF was analysed in mitigating $\mathrm{CO}_{2}$ emissions.. An uncontrolled dumping and burning of the wastes at the institution's dump site resulted in the release of about $25,746.70 \mathrm{~kg} /$ ton of $\mathrm{CO}_{2}$ emissions into the environment of the institution every day. Through the application of the fabricated SAMRF, it was established that a total of $24,050.44 \mathrm{~kg} /$ ton of $\mathrm{CO}_{2}$ emissions was mitigated. The Facility provided solution to the identified gap in separate collection of recyclables at source which has been a challenge to resource recovery in municipal solid waste management at tertiary institution's level in Nigeria.

Key Words: Greenhouse Gas, Municipal Solid Waste, Sorting, Recyclables, Carbon foot print

\section{INTRODUCTION}

Solid waste mismanagement is a social burden that requires the introduction of reliable public policies, including recycling principles and technological facilities. Waste generation is said to be directly related to population, urbanization and affluence; SPREP (2009), observed that waste generated daily consist of biodegradable organic matters like kitchen 


\section{International Journal of Engineering Applied Sciences and Technology, 2020 \\ Vol. 5, Issue 4, ISSN No. 2455-2143, Pages 32-38 \\ Published Online August 2020 in IJEAST (http://www.ijeast.com)}

waste, garden waste and paper. When organic waste decomposes, Carbon Dioxide $\left(\mathrm{CO}_{2}\right)$, Nitrous Oxide $\left(\mathrm{N}_{2} \mathrm{O}\right)$ and Methane gas $\left(\mathrm{CH}_{4}\right)$ are created. Methane is created when there is no air present while carbon dioxide is the natural product when anything rots in air. Both carbon dioxide and methane are Greenhouse Gases (GHG), which contribute to global warming and climate change (Bogner, Pipatti, Hashimoto, 2008). As established in international scientific circles, the buildup of $\mathrm{CO}_{2}$ and other Greenhouse Gases in the atmosphere will result into major environmental changes like rising sea levels that may cause flooding of coastal as well as river delta communities; shrinking of mountain glaciers and reduction of snow cover which may diminish fresh water resources; as well as the spread of infectious diseases and increased heatrelated mortality; possible loss in biological diversity and other effects on ecosystems; and agricultural shifts such as impacts on crop yields and productivity (McCarthy, 2001).

Waste management practices for developed and developing nations or for urban and rural areas are at variance including residential and industrial, producers. The management of $\mathrm{n}$ on-hazardous residential and institutional wastes in city areas are statutorily the responsibility of the local government authority, while the management of non-hazardous commercial and industrial waste is usually placed on the soldiers of the generators (Adeyemi, 2009). There are a number of methods for managing the various types of waste based on type of waste materials and available land uses. The most used waste management methods are sanitary landfill which is the disposal of waste material or refuse by burying it in natural or excavated holes and/ or depressions and incineration which is burning the refuse to ashes. There is also the compost heaps where the refuse is left to degrade by aerobic microorganism and it is used as fertilizer. There is also the method referred to as resource recovery. It is a process of recovering energy and reusable materials from solid waste at source. Some of these methods is said to cause additional harm to the environment. (Adeniyi, 2014).

The world can achieve sustainable development in waste management by utilizing the principle of 3Rs (Reduce, Reuse and Recycle). The best means of utilizing this principle to mitigate against the GHG is by implementing Material Recovery Facility (MRF). Hosanky (2015) defined MRF as solid-waste management plant that processes recyclable materials to sell to manufacturers as raw materials for new products. MRF is a purpose designed plant that accepts waste materials, either source sorted or mixed, process and stores them for further use as raw materials in manufacturing and or reprocessed.. Typical materials recovered at MRFs include ferrous metal, aluminum, PET, HDPE, and mixed paper. MRFs may be both clean MRFs and dirty MRFs (LeBlanc, 2016).

\section{METHODOLOGY}

\section{A. Study Area: Federal Polytechnic Ede}

Ede is a town in Osun State, southwestern Nigeria. It lies along the Osun River at a point on the railroad from Lagos, 180 kilometers southwest, and at the intersection of roads from Oshogbo, Ogbomosho, and Ife. The Federal Polytechnic, Ede is a Nigerian tertiary institution that was established in 1992. It is located in Ede, a town in Osun State, Southwestern Nigeria. It is a National Diploma and Higher national awarding institution. As at the time of this research work, the polytechnic has two campuses tagged North and South Campuses with a total population of 1243 staff and student's population of 11340 out of which an average of 500 students resides in the hostels. The South campus is occupied by two schools/faculties; the School of Engineering Technology (SET) and the School of Environmental Studies (SES) while the North campus houses the remaining two schools, School of Applied Sciences (SAS) and School of Business Studies (SBS). The Administrative block, Bursary, Medical center, Students' Affairs office, Works Department, Sports Facilities, Mini Market and Students' Hostels, There are total of twenty departments each with Head of Department (HOD) office and minimum of five offices for lecturers. The residential area i.e. the students' hostel was built for male and female students separately, the male hostel has 50 room while the female hostel has 80 rooms with four students in each room. There are about fifty (50) 80-100 seater capacity classrooms in the Institution and 10 number 300-500 seater capacity lecture theaters. The mini market areas have food canteens, laundry, tuck shops and hair salons where waste forms that include leather produce, human and artificial hair, liquid discharge with other synthetic chemicals and waste products are discharged.

\section{B. Methods to Determine the Current State of Waste Components and Management Methods in Federal Polytechnic Ede.}

The Federal Polytechnic Ede is an heterogeneous institution comprising of different categories of people, buildings and environments The waste generated in the polytechnic therefore varies covering residential, institutional, medical, MSW, Liquid waste etc. This research work focused basically on the MSW 


\section{International Journal of Engineering Applied Sciences and Technology, 2020 \\ Vol. 5, Issue 4, ISSN No. 2455-2143, Pages 32-38 \\ Published Online August 2020 in IJEAST (http://www.ijeast.com)}

generated in the polytechnic residential, market/commercial, academic areas and office places. The current state of waste management in the polytechnic was examined through direct observations of the wastes collection, storage, transportation and disposal strategies in the Institution. Conduct of interview with the waste generators and works department of the institution was as well carried out

\section{Observation of the Current State of Waste Management}

A thorough one session monitoring (observation) of the waste management methods of the various sectors in the institution was carried out at the Office/Academic Areas, Residential and Commercial Area.

\section{Methods to Determine the GHG/Carbon Emissions.}

The $\mathrm{CO}_{2}$ emissions from the generated wastes in the offices, academic, commercial and residential areas of the polytechnic were calculated to determine the percentage of these gases in the polytechnic environment. The Intergovernmental Panel on Climate Change (IPCC) recommendations was used to estimate the level of GHG emissions based on the current waste generation and management practices of MSW in the institution.

\section{E. Assessment of problems Related to current situation}

Through direct observation of waste generation mechanism, waste collection strategies, transportation and disposal methods, the quantity and component of wastes generated and deposited at the dump site of the Institution was established. The parameters for designing the prototype semi- automated MRF was established from the waste quantity and characteristics.

\section{F. Method to Develop Prototype of a Semi Automated Material Recovery Facility (AMRF) to Mitigate the Carbon Emissions Generated.}

The prototype semi-automated Material Recovery Facility (SAMRF) was designed and fabricated using locally available materials and technology. Amount of wastes generated and collected in the Institution which was $747.5 \mathrm{~kg}$ of MSW and its identified components (Akinjoghin, Sridhar, Coker, 2019) form the equipment design basis. The equipment was demonstrated at separating the constituents of the wastes generated in the institution. The GHG and carbon emission reduction from wastes through the application of the SAMRF was established and compared with the emissions generated initially into the environment of the institution. The performance of the developed prototype Semi-Automated Material Recovery Facility was established

\section{RESULTS AND DISCUSSION}

\section{A. Waste Transportation, Disposal and Treatment}

The wastes collected and disposed of from the sources mentioned earlier were carried out by open pit dumping, open dumping and open air burning, The Institution has a designated area where the collected wastes were deposited for open air burning as shown in Plate 1. The Institution has no formal transportation facility for transporting the collected wastes to the dump site. The mobile dust bins were rolled/dragged to the dump site by the staff of the collecting entity of the Institution on daily basis for hostels and weekly basis for other areas except the mini market. The collection at the mini market is unscheduled. Some individuals especially the operators of the mini market take their wastes to the dump site in persons. Many of the inpatient waste depositors deposited wastes just by the road side or along the short route to the pit dug at the dump site and or burn them at an unapproved point in the mini market as shown in Plates 2

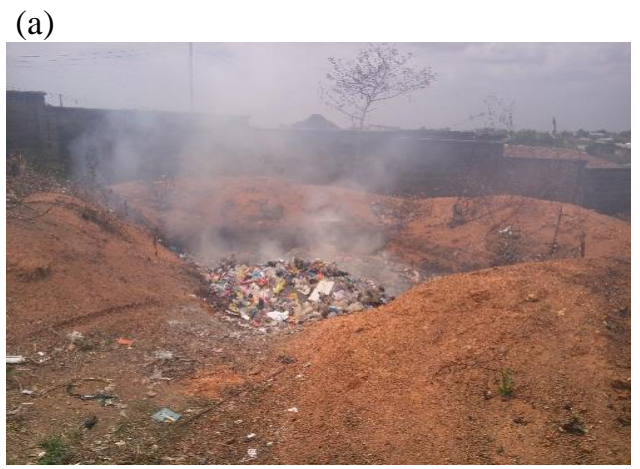

(b)

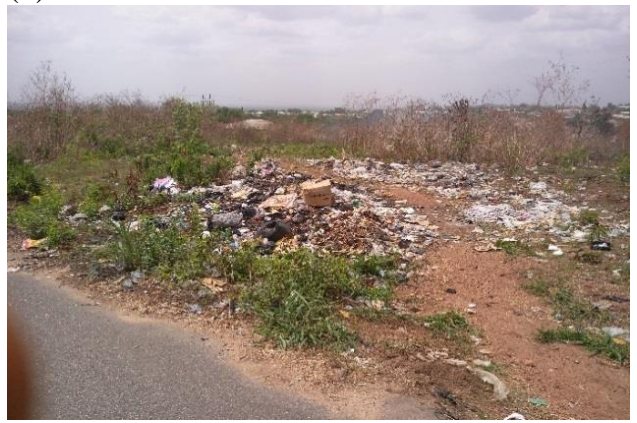




\section{International Journal of Engineering Applied Sciences and Technology, 2020 \\ Vol. 5, Issue 4, ISSN No. 2455-2143, Pages 32-38 \\ Published Online August 2020 in IJEAST (http://www.ijeast.com)}

Fig 1: (a) Dump site (b) Waste deposited by the road side

(a)

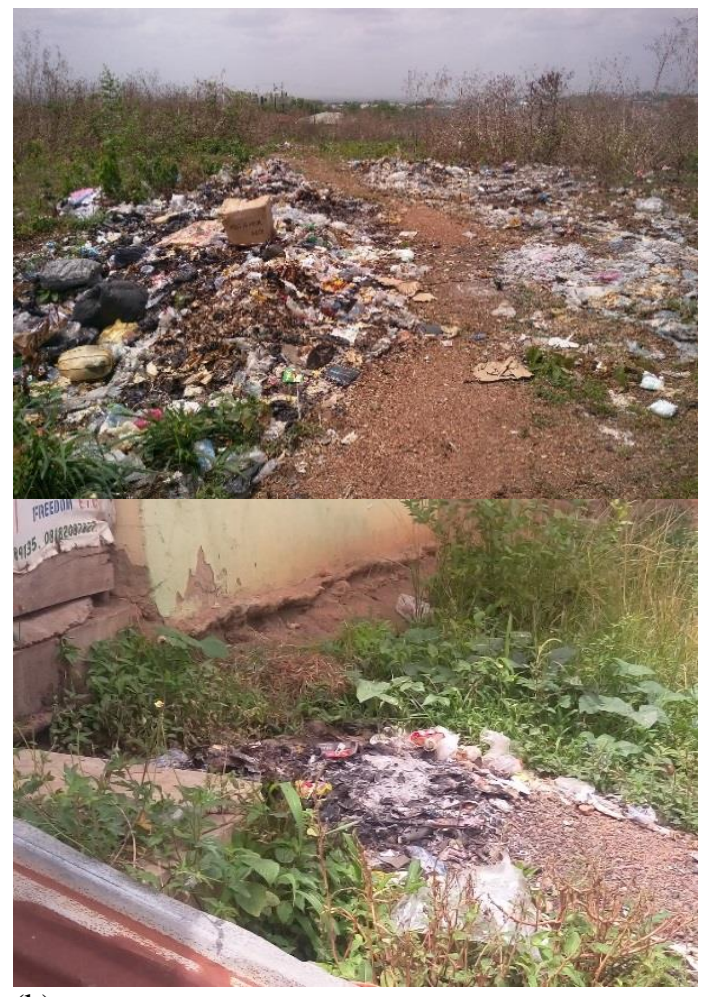

(b)

Fig 2: (a) Wastes deposited along the dump site route. (b) Illegal Burning point in the mini mart

After the waste collection facilities were carefully inspected at the final disposal site, the types of waste identified from the study area are shown in table 1 below.

Table 1: Sources and Types of waste from FPE Premises

\begin{tabular}{ll}
\hline Source & Type of Waste \\
\hline $\begin{array}{l}\text { Administrative } \\
\text { area }\end{array}$ & $\begin{array}{l}\text { Nylon, paper, Plastic, wood, } \\
\text { leaves, can }\end{array}$ \\
$\begin{array}{l}\text { Academic area } \\
\text { Commercial Area plastic, electronic } \\
\text { waste, glass, metal, can, } \\
\text { nylon }\end{array}$ & $\begin{array}{l}\text { Food leftover, bones, vegetal } \\
\text { matter, food preparation } \\
\text { waste, ash, tins, bottles, } \\
\text { paper, plastic, nylon, cloth, } \\
\text { leather, leave, electronic } \\
\text { waste and sand, }\end{array}$ \\
\end{tabular}

\begin{tabular}{|c|c|}
\hline $\begin{array}{l}\text { Residential } \\
\text { area(Hostels) }\end{array}$ & $\begin{array}{l}\text { Paper, food remnants, food } \\
\text { preparation wastes, plastic, } \\
\text { textile } \\
\text { waste, leather, cans, } \\
\text { vegetable matter, glass }\end{array}$ \\
\hline $\begin{array}{l}\text { Recreational } \\
\text { area(Sports } \\
\text { pavilion) }\end{array}$ & $\begin{array}{l}\text { Paper, plastic, glass, cans, } \\
\text { leather }\end{array}$ \\
\hline $\begin{array}{l}\text { Recreational } \\
\text { area(Staff club) }\end{array}$ & $\begin{array}{l}\text { Food leftover, bones, food } \\
\text { preparation waste, ash, tins, } \\
\text { bottles, paper, plastic, glass } \\
\text { and leaves }\end{array}$ \\
\hline Health Center & $\begin{array}{l}\text { Sharps, glasses, plastics, } \\
\text { cotton wools, bandages and } \\
\text { food leftovers }\end{array}$ \\
\hline $\begin{array}{l}\text { Hospitality, } \\
\text { Leisure } \\
\text { Tourism Dept. }\end{array}$ & $\begin{array}{l}\text { Paper, nylon, cloth, plastic, } \\
\text { waste food, vegetable } \\
\text { matters, food preparation } \\
\text { waste, leaves }\end{array}$ \\
\hline
\end{tabular}

Table 2: Composition of solid waste generated in FPE in Percentage

\begin{tabular}{|llll}
\hline Waste component & $\begin{array}{l}\text { Weight } \\
\text { waste } \mathbf{( k g )}\end{array}$ & $\begin{array}{l}\text { Percentage } \\
\text { weight }\end{array}$ & by \\
\hline Paper & 210 & 28 \\
\hline Plastic and Nylons & 187.5 & 25 \\
\hline Textile & 13 & 2 \\
Leather & 7.5 & 1 \\
Metal, Tin and Can & 75 & 10 \\
Glass and Bottles & 22.5 & 3 \\
Biodegradables & 180 & 24 \\
Others & 52 & 7 \\
\hline Total & 747.5 & $\mathbf{1 0 0}$ \\
\hline
\end{tabular}

\section{B. $\mathrm{CO}_{2}$ Emission Due to Current Waste Management Practice in FPE}

Open burning is currently the treatment choice for collected municipal solid wastes (MSW) in FPE. Theoretically and virtually, all the volatile carbon content in MSW are converted into $\mathrm{CO}_{2}$ emissions during burning. During burning of MSW, most of the greenhouse gases (GHGs) in the emissions consist of $\mathrm{CO}_{2}$ and $\mathrm{N}_{2} \mathrm{O}$. of which $\mathrm{CO}_{2}$ being higher and more significant than $\mathrm{N}_{2} \mathrm{O}$.

$\mathrm{CO}_{2}$ emissions, in particular, have played the most significant role on global warming

The Intergovernmental Panel on Climate Change (IPCC) (2006) formula for calculating $\mathrm{CO}_{2}$ emissions from waste incinerator or open burned uses the fossil carbon content burnt in the waste as the input parameter. The product of the oxidation factor and 
amount of fossil carbon oxidized give the $\mathrm{CO}_{2}$ emission. The related data involve the waste components, total mass, dry matter content, total carbon content, fossil carbon fraction and oxidation factor

The defined categories of waste were household waste, and commercial/institutional waste. This agrees well with the general definition for MSW used in the IPCC Guidelines.

This study used Tier $2 \mathrm{a}$ of IPCC to estimate the amount of $\mathrm{CO}_{2}$ emissions produced during the open burning after wastes were transported to the dump site and were sampled to reveal the waste physical composition.

Table 3: $\mathrm{CO}_{2}$ Emission Estimate Based on the Total Amount of Waste Combusted

\begin{tabular}{|c|c|c|c|}
\hline $\begin{array}{l}\text { WASTE } \\
\text { COMPO- } \\
\text { NENT }\end{array}$ & $\begin{array}{l}\text { Weight of } \\
\text { Waste } \\
\text { (kg/day) }\end{array}$ & $\begin{array}{l}\text { Weight } \\
\text { of Waste } \\
\text { (Gg/yr) } \\
\text { MSW }\end{array}$ & $\begin{array}{l}\text { Dry } \\
\text { Content } \\
(\%)\end{array}$ \\
\hline Paper & 210 & 0.767 & .78 \\
\hline $\begin{array}{l}\text { Plastic } \\
\text { and } \\
\text { Nylons }\end{array}$ & 187.5 & 0.0684 & 1 \\
\hline Textile & 13 & 0.0047 & .82 \\
\hline Leather & 7.5 & 0.0027 & .83 \\
\hline $\begin{array}{l}\text { Metal, } \\
\text { Tin and } \\
\text { Can }\end{array}$ & 75 & 0.0274 & 0 \\
\hline $\begin{array}{l}\text { Glass and } \\
\text { Bottles }\end{array}$ & 22.5 & 0.0082 & 0 \\
\hline $\begin{array}{l}\text { Biodegra } \\
\text { dables }\end{array}$ & 180 & 0.0657 & .40 \\
\hline Others & 52 & 0.0190 & .10 \\
\hline Total & 747.5 & 0.9631 & \\
\hline \multicolumn{4}{|c|}{ Table 4: Design Parameters for the SAMRF } \\
\hline \multicolumn{2}{|c|}{ Parameter Description } & \multicolumn{2}{|c|}{ Assumed Value } \\
\hline \multicolumn{2}{|c|}{ Speed of the Motor } & \multicolumn{2}{|c|}{$0.17 \mathrm{~m} / \mathrm{s}$} \\
\hline \multicolumn{2}{|c|}{ Conveyor width } & \multicolumn{2}{|l|}{$1.20 \mathrm{~m}$} \\
\hline \multicolumn{2}{|c|}{$\begin{array}{l}\text { Sorting Length per } \\
\text { sorter }\end{array}$} & \multicolumn{2}{|l|}{$1.20 \mathrm{~m}$} \\
\hline \multicolumn{2}{|c|}{ Total sorting length } & \multicolumn{2}{|l|}{$3.60 \mathrm{~m}$} \\
\hline \multicolumn{2}{|c|}{ Total conveyor length } & \multicolumn{2}{|l|}{$4.35 \mathrm{~m}$} \\
\hline \multicolumn{2}{|c|}{ Conveyor waste depth } & \multicolumn{2}{|l|}{$0.15 \mathrm{~m}$} \\
\hline \multicolumn{2}{|c|}{ Average waste density } & \multicolumn{2}{|l|}{$160 \mathrm{~kg} / \mathrm{m}^{3}$} \\
\hline \multicolumn{2}{|c|}{ Effective work day } & \multicolumn{2}{|c|}{$\begin{array}{l}7 \text { Hours per day }(2,500 \\
\text { S/Day) }\end{array}$} \\
\hline
\end{tabular}

\begin{tabular}{lll}
\hline $\begin{array}{l}\text { Number of Pickers } \\
\text { Sorter Efficiency per }\end{array}$ & 6.5 \\
day & & \\
$\begin{array}{l}\text { Average Weight of } 1000 \mathrm{~kg} / \mathrm{ton} \\
\text { Waste per ton }\end{array}$ & & \\
\hline
\end{tabular}

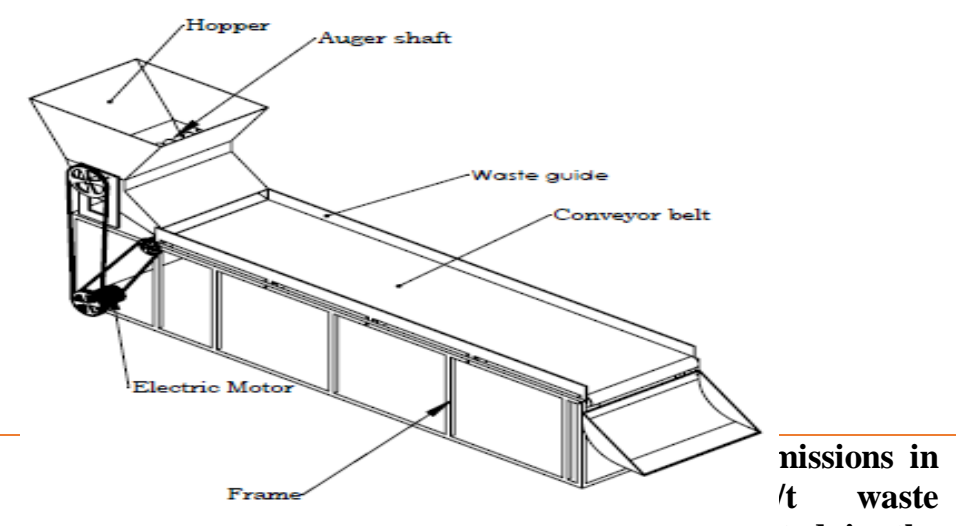

Fig 3: Schematic Diagram of the Semi Autqmatizution $163.8 \quad$ Material Regcovery. 6 Facility $.58 \quad 3667 \quad 5002.12$

187.5 Table 5: Materials and Design Specification for'the ${ }^{36} .01$ SAMRF

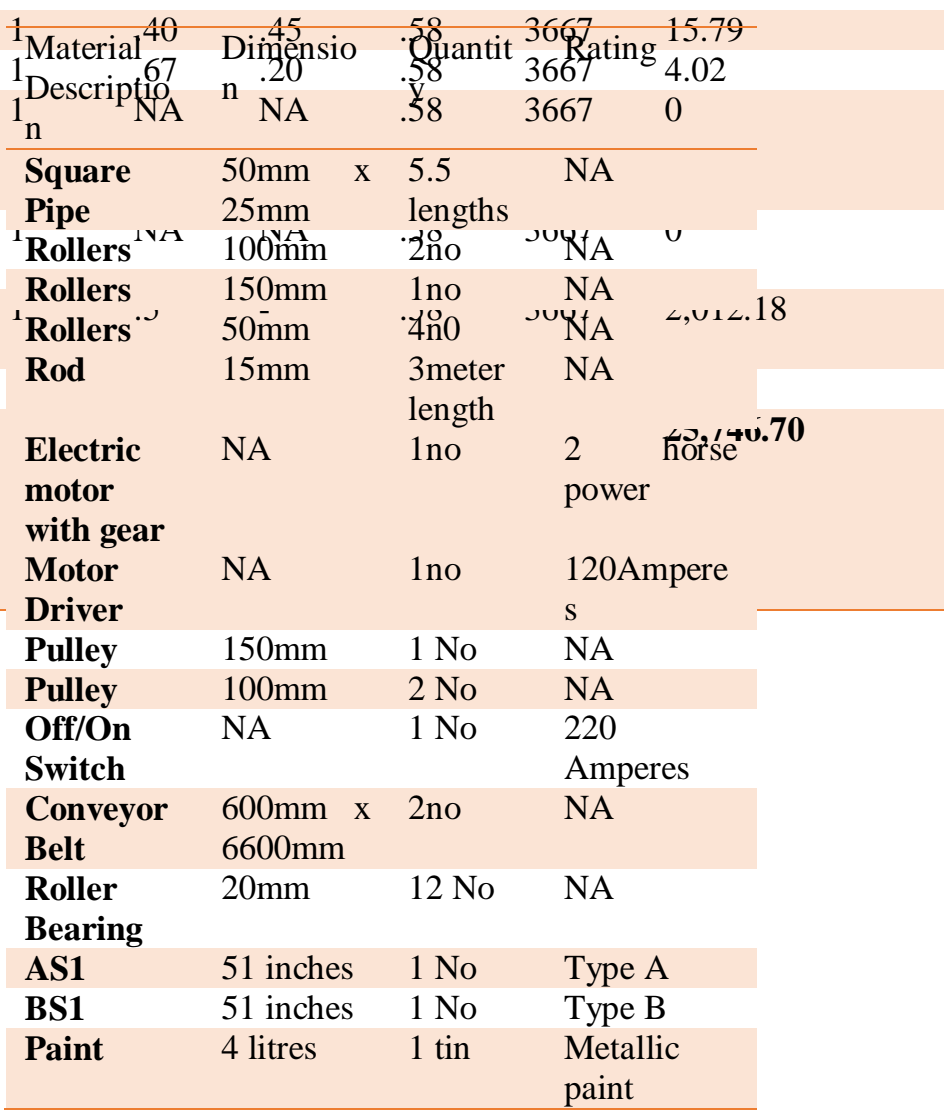




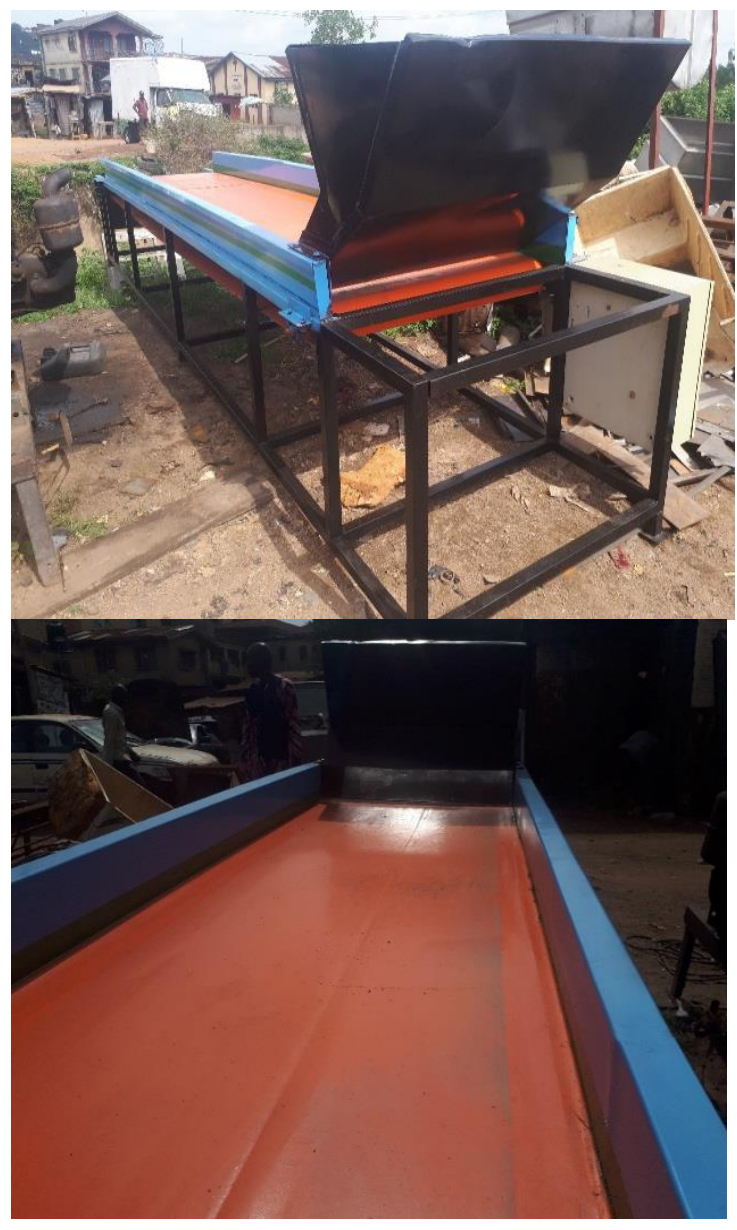

Fig 4: Pictorial View of the Fabricated Semi Automated Material Recovery Facility

Table 6.below shows the result obtained when the equipment was demonstrated. The result obtained indicates that the estimated carbon dioxide emission mitigated was $24,050.44 \mathrm{~kg} /$ ton of carbon dioxide

Table 6: $\mathrm{CO}_{2}$ Emission Estimate Based on the Total Amount of Waste Combusted after Shorting Using the Fabricated SAMRF

\begin{tabular}{llllll}
\hline $\begin{array}{l}\text { Metal, } \\
\text { Tin and } \\
\text { Can }\end{array}$ & 0 & 0.0274 & 0 & 0 & 1 \\
$\begin{array}{l}\text { Glass and } \\
\text { Bottles }\end{array}$ & 0 & 0.0082 & 0 & 0 & 1 \\
$\begin{array}{l}\text { Biodegra } \\
\text { dables }\end{array}$ & 0 & 0.0657 & .40 & 72 & 1 \\
\hline $\begin{array}{l}\text { Others } \\
\text { Total }\end{array}$ & 52 & 0.0190 & .10 & 5.2 & 1 \\
\hline
\end{tabular}

\section{CONCLUSION}

1. The composition of the wastes are similar to the composition of wastes obtained from other tertiary institutions earlier reviewed through literatures. MSW in FPE contains the following materials, which are considered recyclable: ferrous and non-ferrous metals, paper/cardboard, plastics, textiles (including cloth and leather), glass and non- recyclable biodegradable items

2. The uncontrolled dumping and burning of the MSW in FPE was responsible for emission of about $25,746.70 \mathrm{~kg} / \mathrm{ton}$ of $\mathrm{CO}_{2}$ into the environment of the institution on daily basis which was needed to be mitigated.

3. To mitigate the above $\mathrm{CO}_{2}$ emissions, a mixed Semi Automated Material Recovery Facility (SAMRF) was designed and fabricated. This facilitated the treatment of the wastes such that recyclables from mixed wastes were recovered, re-used and recycled. An estimated carbon dioxide emissions mitigated was 24, 050.44 $\mathrm{kg} / \mathrm{ton}$.

\section{REFERENCES}

1 Adeniyi T. F. (2014): “Assessment of Solid Waste Management in Samaru Zaria, Nigeria"; An Msc Thesis in Department Of Geography Faculty Of Science Ahmadu Bello University, Zaria Nigeria accesses from

http://kubanni.abu.edu.ng:8080/jspui/bitstrea $\mathrm{m} / 123456789 / 6081 / 1 /$ assessment $\% 20$ of $\% 20$

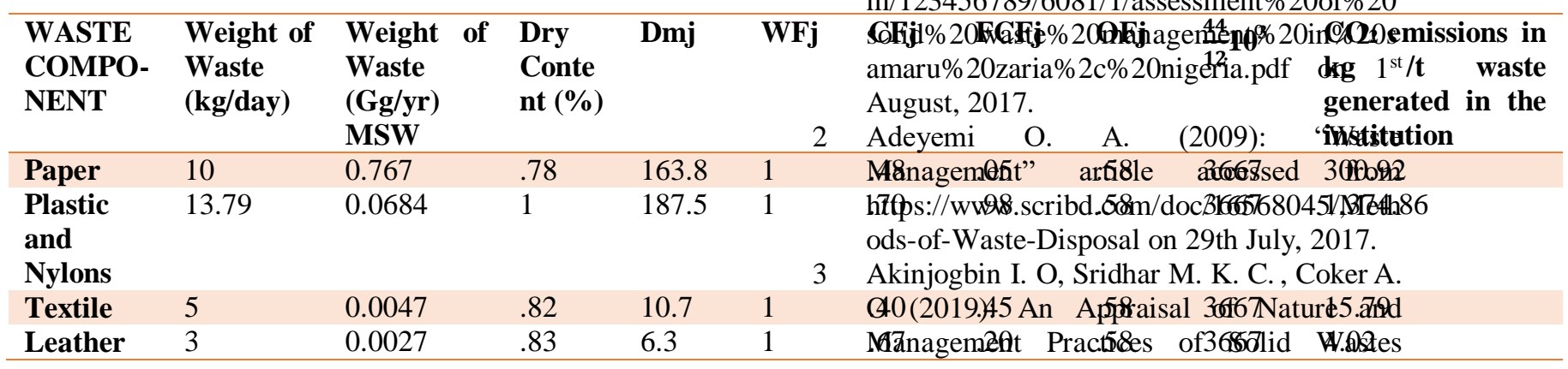


Generated in a Tertiary Institution in Nigeria, (pp 63- 75) WORLD Journal of Engineering Research and Technoloy (WJERT), Research Institute, Bhandara, Maharashtra, India, Vol. . November, 2019

4 Bogner J., Pipatti R., Hashimoto S., (2008): "Mitigation of global greenhouse gas emissions from waste: conclusions and strategies from the Intergovernmental Panel on Climate Change (IPCC) Fourth Assessment Report. Working Group III (Mitigation)" a publication of SAGE Journals on Waste Management and Research Vol 26(1) accessed from http://journals.sagepub.com/doi/abs/10.1177 /0734242X07088433 on 12th July, 2017.

5 Hosansky D., (2015) "Materials recovery facility (MRF)". Accessed from https://www.britannica.com/technology/mat erials-recovery-facility on 1st August, 2017.

6 McCarthy, J.J. (2001): "Climate Change (2001): Impacts, Adaptation, and Vulnerability" (pp. 9 - 13) IPCC. Cambridge University Press, accessed from an article from https://earthzine.org/2010/10/04/potentialimpacts-of-climate-change-on-solid-wastemanagement-in-nigeria/ on $29^{\text {th }}$ July, 2017

7 SPREP (2009): "Waste \& Climate Change" a publication of Secretariat of the Pacific Regional Environment Programme accessed from https://www.sprep.org/climate_change/PYC C/documents/ccwaste.pdf on 23rd July, 2017. 